\title{
Peer marking of OSCEs within a UK pharmacy undergraduate programme - student views
}

\author{
Rhian Deslandes (iD) Louise Hughes \\ School of Pharmacy and Pharmaceutical Sciences, Cardiff University, United Kingdom
}

\author{
Keywords \\ Formative \\ Near-peer \\ OSCES \\ Peer marking \\ Pharmacy student
}

\author{
Correspondence \\ Rhian Deslandes \\ School of Pharmacy and Pharmaceutical Sciences \\ Cardiff University \\ King Edward VII Avenue \\ Cardiff \\ CF10 3NB \\ United Kingdom \\ DeslandesRE@cardiff.ac.uk
}

\begin{abstract}
Objective: Objective Structured Clinical Examinations (OSCEs) assess competencies in undergraduate pharmacy students. Students in senior years marked those in the year below during a formative OSCE. Method: The study explored the views of students who marked and had been marked by peers via an online survey. Ethical approval was obtained. Results: $115(36 \%)$ of markers and 114 (35\%) of those who were marked responded. Most students who were marked agreed that it was a positive experience and were comfortable receiving feedback from their peers; there were varied views on student marker consistency and how they were not equivalent to staff markers. Student markers felt prepared and confident giving feedback and marks. Markers felt it was a beneficial experience. Working collaboratively with another marker and assessing more than one student was valuable to allow discussion and inform their own OSCE. Conclusion: Overall, students supported this initiative, which has now been embedded into the undergraduate programme.
\end{abstract}

\section{Introduction}

An Objective Structured Clinical Examination (OSCE) was first described by Harden and authors (1975) and is commonly used to assess competence in a number of health professions. Students are directly assessed upon performing a specific goal-orientated task, whilst communicating with a simulated patient. The scenarios are specifically timed, with each student performing identical stations. Due to its objectivity, this type of assessment has become more popular within the training of pharmacy undergraduate students and has been shown to be both 'consistent and dependable' (Quero Munoz et al., 2005). Indeed, the pharmacy regulatory body within the United Kingdom (UK), the General Pharmaceutical Council (GPhC) advocates the use of OSCEs as a means of assessing undergraduate pharmacy student competence (GPhC, 2011). Miller's pyramid effectively illustrates the level of performance a student must achieve, with an OSCE allowing staff to assess on a 'shows how' level, whereby students address a learning outcome within a real-life or simulated situation (Miller, 1990). The use of an OSCE to assess common, real-life, pharmacy-based scenarios is critical to ensure that pharmacy undergraduate students have developed the necessary skills and knowledge to perform in their role and complements more traditional paper-based assessments. Quero Munoz and authors (2005) believe that the use of an OSCE as part of the assessment schedule provides a 'more robust vehicle for assessing competency'. Professional practice requires pharmacists to support their peers; providing constructive feedback is therefore an integral part of their role and a key skill to develop (GPhC, 2011).

OSCEs are used, not only in a summative assessment to assess a student's competence but as a means of providing feedback within a formative or mock environment. It is the formative assessment that is focussed upon in this paper. This latter opportunity supports the students to identify gaps in knowledge 
and communication skills, providing constructive feedback to progress. OSCEs are marked whereby markers assign two scores. The first mark is termed the 'analytical checklist' score, which describes the number of desirable information gathering or provision points the student achieves. The second mark, termed the 'overall performance' score, describes how well the student has addressed the station, based on their information gathering/provision skills and the manner in which they have dealt with the scenario, including their communication skills. OSCEs have traditionally been marked solely by an academic member of staff, which in itself requires high staff numbers and workload, and a high financial burden (Kelly and Murphy, 2004; Chenot et al., 2007; Brown et al., 2015) compared with other styles of assessment, such as written assessments. However, with the increasing number of students and the resulting burden on staff, it is imperative to explore alternative avenues of supporting students appropriately.

Peer review and teaching by more senior students are well recognised to support those in their formative years. Peer assisted learning (PAL) opportunities have been widely utilised within healthcare education and, more specifically, within medical education. A number of studies have evidenced that utilising peers as OSCE examiners within a formative or teaching opportunity, rather than a summative environment, is a valid, justified tool within medical, dental and nurse education (Ogden et al., 2000; Chenot et al., 2007; Moineau et al., 2011; Burgess et al., 2013; Ibhler et al., 2015; Saunders et al., 2019) and has been utilised as far back as in 1990 (Harris \& Miller, 1990).

As a result, the School of Pharmacy took the decision to conduct formative OSCEs utilising peer marking as opposed to staff marking alone. The OSCEs were already established within the school; this paper focuses on the addition of peer markers within the formative test. The undergraduate programme in the UK consists of four years (GPhC, 2020); therefore, each of the second, third and fourth-year students were able to mark some of their peers in the previous year. All students were given this opportunity and scheduled to mark the formative test of those in the year below them. Students worked in marker pairs so that they could support each other; these were pre-allocated before the day. Each individual student marker submitted marks, and therefore each student marked by a peer from the year above received two mark sheets to maximise the feedback provided. There was an opportunity to mark multiple students in the year below, typically four students per marker pair. Markers were provided with training before the day of the OSCE via a year specific face to face session with two of the
OSCE leads (authors). This included how to interpret the marking criteria and a practice marking prerecorded mock OSCEs to allow for discussion and to ensure that markers were marking at the correct level for the year of the programme. The aim of this session was to ensure that the marking process was valid and reliable. On the day of the OSCE itself, marking was recorded on an iPad, utilising OSCE specific software (practique). Each student was provided with their own iPad and given an opportunity to learn how to use the software before seeing their first student. As well as the peer marker, all students were encouraged to engage with the actor who played the part of the patient. There was an opportunity between students for markers to discuss the scenario they had just witnessed to help inform their feedback comments. Year two markers also had a staff member present during their time as a marker. This was felt necessary as they were marking year one students who had never undertaken an OSCE before, and they had only ever experienced an OSCE themselves the previous year. These markers were encouraged to discuss the year one scenarios with both the staff member and the actor present. The marks and feedback comments were later provided to those being marked in order to support them in their development.

There is evidence in the literature that such an exercise has been well received by both student markers and those being marked. Students taking on the role of markers would also use the opportunity to facilitate their learning, reflection and professionalism (Burgess et al., 2013). The use of peers in a formative assessment has been shown to prepare and improve a student's subsequent performance in their summative assessment, increase confidence and reduce anxieties which are associated with this type of assessment (Young et al., 2014; Fletcher \& Day, 2015; Zhang \& Rabatsky, 2015; Saunders et al., 2019). However, the available literature is mainly focused on using PAL in medical OSCEs, whereby a number of different skills are being assessed, rather than the more communicationbased assessment conducted within a pharmacy undergraduate training programme. There is no equivalent literature within the field of pharmacy to evaluate feedback from students on this type of assessment.

The aim of this study was to explore views of student markers and those being marked on the utilisation of peer markers during a formative OSCE. The view of the markers focused on how the OSCE was conducted, the process of marking and providing feedback and the perceived personal benefits of undertaking a marker role. The students who were being marked provided feedback on being marked by a senior peer and the quality of the feedback provided. 


\section{Methods}

An online survey (hosted through 'Online Surveys') was determined to be the most appropriate method to collect data from students who had participated in the peer marked mock OSCEs. The survey was made available to all students who engaged with the formative OSCE; as such total population sampling was utilised. The research team produced a number of statements based on the literature, together with anecdotal feedback from staff and students involved in the mock OSCEs. The statements were presented with a five-point Likert-style response 1) strongly agree; 2) agree; 3) neither agree nor disagree; 4) disagree; 5) strongly disagree); and a not applicable option to use, where necessary. Students were also given the opportunity to provide comments within free text boxes where they wished to provide further detail or clarity. These comments were analysed via thematic analysis and quotes utilised to illustrate the findings from the questionnaire.

The questionnaire contained two major sections - one relating to acting as a marker and one relating to being marked by peers, as previously outlined. The pharmacy degree consists of four years. Students in years two to four marked those in years one to three respectively. Those in year one did not mark any students, and year four students were marked by members of academic staff. As such, students were asked to complete the section(s) relevant to the role(s) they played in the mock OSCE (i.e. marker and/or marked student).

All students were asked to complete a brief demographic section 1) year of study; 2) gender; 3) fee status; 4) home or overseas student; and whether they marked and/or were marked by other students. Following approval from the Cardiff School of Pharmacy and Pharmaceutical Sciences Research Ethics Committee, the link to the survey, together with participant information, was circulated to all students in the school $(n=430)$ via e-mail. Implied consent was taken upon submission of the questionnaire. A followup e-mail was sent two weeks after the survey opened. After the closing date, data were extracted into SPSS for analysis. After obtaining descriptive statistics, inferential analysis to consider question responses in relation to demographic data 1) year of study; 2) gender; 3) fee status was undertaken using the Kruskal Wallis test for non-parametric unpaired data, where the null hypothesis (i.e. there was no difference between the views of students with different characteristics) was rejected, post hoc testing using the Bonferroni correction was undertaken.

\section{Results}

In total, 162 students responded to the survey (38\% of the undergraduate pharmacy students $(n=430)$ at the study time). Of the 316 who were in years which acted as markers, 115 (36\%) responded, while of the 328 who were in years where their mock was marked by other students, 114 (35\%) responded. Key demographics of the students who responded are shown in Table I.

Table I: Key demographics showing numbers of students who responded to the surveys

\begin{tabular}{|c|c|c|c|}
\hline & & $\begin{array}{l}\text { Marked by } \\
\text { a student in } \\
\text { the year } \\
\text { above } \\
(n=114) \\
n(\%)\end{array}$ & $\begin{array}{c}\text { Acted as a } \\
\text { marker for } \\
\text { other } \\
\text { students } \\
\text { (n=115) } \\
n(\%)\end{array}$ \\
\hline \multirow[t]{5}{*}{ Year of study } & $\begin{array}{l}\text { Year } 1 \\
(n=115)\end{array}$ & 45 (39.5\%) & - \\
\hline & $\begin{array}{l}\text { Year } 2 \\
(n=109)\end{array}$ & 36 (31.6\%) & $37(32.2 \%)$ \\
\hline & $\begin{array}{l}\text { Year } 3 \\
(n=104)\end{array}$ & 33 (28.9\%) & $33(28.7 \%)$ \\
\hline & $\begin{array}{l}\text { Year } 4 \\
(n=102)\end{array}$ & - & 45 (39.1\%) \\
\hline & Total & 114 & 115 \\
\hline \multirow[t]{4}{*}{ Gender } & Female & 85 (74.6\%) & $87(75.7 \%)$ \\
\hline & Male & $28(24.6 \%)$ & 27 (23.5\%) \\
\hline & Other & $1(0.8 \%)$ & $1(0.9 \%)$ \\
\hline & Total & 114 & 115 \\
\hline \multirow[t]{4}{*}{ Fee status } & Home & 96 (84.2\%) & 105 (91.3\%) \\
\hline & Overseas & $15(13.2 \%)$ & 9 (7.8\%) \\
\hline & $\begin{array}{l}\text { Prefer not to } \\
\text { say }\end{array}$ & $3(2.6 \%)$ & 1 (0.9\%) \\
\hline & Total & 114 & 115 \\
\hline
\end{tabular}

Experiences of students who were marked by a student in the year above

Amongst the 114 students who were marked by a student in the year above them, there was generally positive feedback about the experience (Table II). The majority agreed that it was a good idea to have more experienced students giving them feedback (82\% agreed to some extent), and most were comfortable receiving feedback from a fellow student $(75 \%$ agreed to some extent). In terms of the feedback which was given, most of the respondents found it beneficial in terms of helping them to understand where they did well (77\% agreed to some extent) and where they needed to improve (76\% agreed to some extent). Just over half (56\%) agreed that they changed their approach based on the student feedback they received. Only $13 \%$ disagreed with the statement that the feedback they received was of good quality. 
Table II: Experiences of those marked by students in the year above ( $n=114)$ shown as number (\%)

\begin{tabular}{|c|c|c|c|c|c|c|}
\hline & $\begin{array}{l}\text { Strongly } \\
\text { agree }\end{array}$ & Agree & $\begin{array}{c}\text { Neither agree } \\
\text { nor disagree }\end{array}$ & Disagree & $\begin{array}{l}\text { Strongly } \\
\text { disagree }\end{array}$ & $\begin{array}{c}\text { Not } \\
\text { applicable }\end{array}$ \\
\hline $\begin{array}{l}\text { The feedback I received from } \\
\text { student markers helped me to } \\
\text { understand what was good about } \\
\text { my performance }(n=114)\end{array}$ & $\begin{array}{c}17 \\
(14.9 \%)\end{array}$ & $\begin{array}{c}71 \\
(62.3 \%)\end{array}$ & $\begin{array}{c}12 \\
(10.5 \%)\end{array}$ & $\begin{array}{c}11 \\
(9.6 \%)\end{array}$ & $\begin{array}{c}3 \\
(2.6 \%)\end{array}$ & - \\
\hline $\begin{array}{l}\text { The feedback I received from } \\
\text { student markers helped me to } \\
\text { understand areas I needed to } \\
\text { improve }\end{array}$ & $\begin{array}{c}14 \\
(12.3 \%)\end{array}$ & $\begin{array}{c}73 \\
(64.0 \%)\end{array}$ & $\begin{array}{c}17 \\
(14.9 \%)\end{array}$ & $\begin{array}{c}7 \\
(6.1 \%)\end{array}$ & $\begin{array}{c}3 \\
(2.6 \%)\end{array}$ & - \\
\hline $\begin{array}{l}\text { The students gave me good quality } \\
\text { feedback }\end{array}$ & $\begin{array}{c}11 \\
(9.6 \%)\end{array}$ & $\begin{array}{c}53 \\
(46.5 \%)\end{array}$ & $\begin{array}{c}34 \\
(29.8 \%)\end{array}$ & $\begin{array}{c}12 \\
(10.5 \%)\end{array}$ & $\begin{array}{c}3 \\
(2.6 \%)\end{array}$ & $\begin{array}{c}1 \\
(0.9 \%)\end{array}$ \\
\hline $\begin{array}{l}\text { The students did not mark me } \\
\text { consistently (i.e. significant } \\
\text { differences between markers) }\end{array}$ & $\begin{array}{c}12 \\
(10.5 \%)\end{array}$ & $\begin{array}{c}36 \\
(31.6 \%)\end{array}$ & $\begin{array}{c}23 \\
(20.2 \%)\end{array}$ & $\begin{array}{c}31 \\
(27.2 \%)\end{array}$ & $\begin{array}{c}11 \\
(9.6 \%)\end{array}$ & $\begin{array}{c}1 \\
(0.9 \%)\end{array}$ \\
\hline $\begin{array}{l}\text { I would rather have verbal } \\
\text { feedback on my mock rather than } \\
\text { paper feedback* }\end{array}$ & $\begin{array}{c}13 \\
(11.4 \%)\end{array}$ & $\begin{array}{c}30 \\
(26.3 \%)\end{array}$ & $\begin{array}{c}22 \\
(19.3 \%)\end{array}$ & $\begin{array}{c}29 \\
(25.4 \%)\end{array}$ & $\begin{array}{c}14 \\
(12.3 \%)\end{array}$ & $\begin{array}{c}6 \\
(5.3 \%)\end{array}$ \\
\hline $\begin{array}{l}\text { It was off-putting having more than } \\
\text { one marker in the room** }\end{array}$ & $\begin{array}{c}20 \\
(17.5 \%)\end{array}$ & $\begin{array}{c}19 \\
(16.7 \%)\end{array}$ & $\begin{array}{c}24 \\
(21.1 \%)\end{array}$ & $\begin{array}{c}35 \\
(30.7 \%)\end{array}$ & $\begin{array}{c}15 \\
(13.2 \%)\end{array}$ & $\begin{array}{c}1 \\
(0.9 \%)\end{array}$ \\
\hline $\begin{array}{l}\text { It was beneficial to have marks and } \\
\text { feedback from more than one } \\
\text { marker*** }\end{array}$ & $\begin{array}{c}36 \\
(31.6 \%)\end{array}$ & $\begin{array}{c}60 \\
(52.6 \%)\end{array}$ & $\begin{array}{c}14 \\
(12.3 \%)\end{array}$ & $\begin{array}{c}3 \\
(2.6 \%)\end{array}$ & - & $\begin{array}{c}1 \\
(0.9 \%)\end{array}$ \\
\hline $\begin{array}{l}\text { I changed my approach to stations } \\
\text { on the basis of the feedback I got } \\
\text { from the student markers }\end{array}$ & $\begin{array}{c}22 \\
(19.3 \%)\end{array}$ & $\begin{array}{c}42 \\
(36.8 \%)\end{array}$ & $\begin{array}{c}27 \\
(23.7 \%)\end{array}$ & $\begin{array}{c}17 \\
(14.9 \%)\end{array}$ & $\begin{array}{c}2 \\
(1.8 \%)\end{array}$ & $\begin{array}{c}4 \\
(3.5 \%)\end{array}$ \\
\hline $\begin{array}{l}\text { It was a good idea to have more } \\
\text { experienced students giving me } \\
\text { feedback }\end{array}$ & $\begin{array}{c}34 \\
(29.8 \%)\end{array}$ & $\begin{array}{c}59 \\
(51.8 \%)\end{array}$ & $\begin{array}{c}15 \\
(13.2 \%)\end{array}$ & $\begin{array}{c}5 \\
(4.4 \%)\end{array}$ & - & $\begin{array}{c}1 \\
(0.9 \%)\end{array}$ \\
\hline $\begin{array}{l}\text { I was comfortable receiving } \\
\text { feedback from another student }\end{array}$ & $\begin{array}{c}33 \\
(28.9 \%) \\
\end{array}$ & $\begin{array}{c}53 \\
(46.5 \%)\end{array}$ & $\begin{array}{c}23 \\
(20.2 \%) \\
\end{array}$ & $\begin{array}{c}3 \\
(2.6 \%)\end{array}$ & $\begin{array}{c}1 \\
(0.9 \%)\end{array}$ & $\begin{array}{c}1 \\
(0.9 \%)\end{array}$ \\
\hline \multicolumn{7}{|c|}{$\begin{array}{l}\text { * Year two students significantly more likely to disagree than Year three students }(p<0.0005 \text {, Bonferroni adjusted) } \\
\text { adjusted) } \\
* * \text { Year one students significantly more likely to agree than Year three students ( } p<0.0005 \text {, Bonferroni adjusted) } \\
* * * \text { Year three students significantly more likely to agree than Year two students ( } p=0.016 \text {, Bonferroni adjusted) }\end{array}$} \\
\hline
\end{tabular}

Students were typically marked by two senior students (although this varied slightly based on logistics, such as absences). While $84 \%$ agreed to some extent that it was beneficial to have more than one student marker giving marks and feedback, around a third (34\%) agreed to some extent that it was off-putting to have more than one marker present in the assessment room, with one student commenting

"Being marked by students you know can be off putting".

There was also mixed feedback regarding the consistency of the markers, with $42 \%$ agreeing and $31 \%$ disagreeing that the student markers did not mark consistently. One student commented,

"I didn't find it useful to have feedback from a student as there was no consistency in the marking between the staff member and student".

\section{Experiences of students who acted as a marker for students in the year below}

Of the 115 markers, the majority ( $n=108,94 \%)$ attended the scheduled marker training session, and by the end of the session, $80 \%$ of those who attended agreed that they felt prepared for marking. On the day (see Table III), all student markers agreed it was helpful to mark more than one student each. Regarding confidence, more students were confident giving feedback ( $84 \%$ agreed) than giving marks (68\% agreed). As for support, 91\% agreed that it was helpful to have more than one marker in each room, but $66 \%$ agreed they wanted a debrief run by staff after marking. Twelve students also said that more support was needed; this related to technical issues such as getting familiar with the software $(n=7)$ and more time or support going through the actual station and its checklist $(n=3)$. One said the session felt rushed, while another wanted a staff marker to give them confidence in their marking: 
"I would have felt more comfortable having a staff member also marking as I was not sure my marking would give the students an adequate reflection of where they were at for the real OSCE".

When it came to the process of marking and giving feedback, students were asked more detailed questions; responses are shown in Table IV. Most reported that they were able to write feedback comments (only $3 \%$ disagreed) and to provide feedback that was constructive ( $4 \%$ disagreed), although $49 \%$ did not feel they had enough time for feedback provision. Lack of time also featured frequently in the free-text comments:

"Sometimes ran out of time trying to finish the analytical checklist, trying to give comments, all before the next student came in".

Table III: Experiences of those who acted as markers for students in the year below $(n=115)$ in terms of on the day organisation - responses shown as number (\%)

\begin{tabular}{|c|c|c|c|c|c|c|}
\hline & $\begin{array}{l}\text { Strongly } \\
\text { agree }\end{array}$ & Agree & $\begin{array}{l}\text { Neither agree } \\
\text { nor disagree }\end{array}$ & Disagree & $\begin{array}{l}\text { Strongly } \\
\text { disagree }\end{array}$ & $\begin{array}{c}\text { Not } \\
\text { applicable }\end{array}$ \\
\hline $\begin{array}{l}\text { It was helpful to mark more than one } \\
\text { student's performance }\end{array}$ & $\begin{array}{c}87 \\
(75.7 \%)\end{array}$ & $\begin{array}{c}28 \\
(24.3 \%)\end{array}$ & - & - & - & - \\
\hline I felt confident providing marks & $\begin{array}{c}24 \\
(20.9 \%)\end{array}$ & $\begin{array}{c}54 \\
(47.0 \%)\end{array}$ & $\begin{array}{c}20 \\
(17.4 \%)\end{array}$ & $\begin{array}{c}15 \\
(13.0 \%)\end{array}$ & $\begin{array}{c}2 \\
(1.7 \%)\end{array}$ & - \\
\hline I felt confident providing feedback* & $\begin{array}{c}33 \\
(28.7 \%)\end{array}$ & $\begin{array}{c}51 \\
(44.3 \%)\end{array}$ & $\begin{array}{c}21 \\
(18.3 \%)\end{array}$ & $\begin{array}{c}9 \\
(7.8 \%)\end{array}$ & $\begin{array}{c}1 \\
(0.9 \%)\end{array}$ & - \\
\hline $\begin{array}{l}\text { Having more than one marker in the } \\
\text { room was helpful }\end{array}$ & $\begin{array}{c}73 \\
(63.5 \%)\end{array}$ & $\begin{array}{c}32 \\
(27.8 \%)\end{array}$ & $\begin{array}{c}6 \\
(5.2 \%)\end{array}$ & $\begin{array}{c}2 \\
(1.7 \%)\end{array}$ & $\begin{array}{c}1 \\
(0.9 \%)\end{array}$ & $\begin{array}{c}1 \\
(0.9 \%)\end{array}$ \\
\hline $\begin{array}{l}\text { I would have liked an opportunity for } \\
\text { markers to debrief with a staff } \\
\text { member at the end of my marking } \\
\text { session }\end{array}$ & $\begin{array}{c}42 \\
(36.5 \%)\end{array}$ & $\begin{array}{c}34 \\
(29.6 \%)\end{array}$ & $\begin{array}{c}18 \\
(15.7 \%)\end{array}$ & $\begin{array}{c}19 \\
(16.5 \%)\end{array}$ & $\begin{array}{c}1 \\
(0.9 \%)\end{array}$ & $\begin{array}{c}1 \\
(0.9 \%)\end{array}$ \\
\hline
\end{tabular}

* Year four students significantly more likely to agree with this statement than year two students ( $p=0.014$, Bonferroni adjusted)

The full analysis is available from the authors on request.

Table IV: Experiences of those who acted as markers for students in the year below $(n=115)$ in terms of providing feedback - responses shown as number (\%)

\begin{tabular}{|c|c|c|c|c|c|c|}
\hline & $\begin{array}{l}\text { Strongly } \\
\text { agree }\end{array}$ & Agree & $\begin{array}{l}\text { Neither } \\
\text { agree nor } \\
\text { disagree }\end{array}$ & Disagree & $\begin{array}{l}\text { Strongly } \\
\text { disagree }\end{array}$ & $\begin{array}{c}\text { Not } \\
\text { applicable }\end{array}$ \\
\hline $\begin{array}{l}\text { I found it hard to know what to } \\
\text { write in the comments box }\end{array}$ & $\begin{array}{c}7 \\
(6.1 \%)\end{array}$ & $\begin{array}{c}27 \\
(23.5 \%)\end{array}$ & $\begin{array}{c}18 \\
(15.7 \%)\end{array}$ & $\begin{array}{c}54 \\
(47.0 \%)\end{array}$ & $\begin{array}{c}9 \\
(7.8 \%)\end{array}$ & - \\
\hline $\begin{array}{l}\text { I was able to write some feedback } \\
\text { comments for all the students I } \\
\text { marked* }\end{array}$ & $\begin{array}{c}42 \\
(36.5 \%)\end{array}$ & $\begin{array}{c}67 \\
(58.3 \%)\end{array}$ & $\begin{array}{c}3 \\
(2.6 \%)\end{array}$ & $\begin{array}{c}3 \\
(2.6 \%)\end{array}$ & - & - \\
\hline $\begin{array}{l}\text { I was able to provide constructive } \\
\text { feedback on the form** }\end{array}$ & $\begin{array}{c}28 \\
(24.3 \%)\end{array}$ & $\begin{array}{c}66 \\
(57.4 \%)\end{array}$ & $\begin{array}{c}16 \\
(13.9 \%)\end{array}$ & $\begin{array}{c}5 \\
(4.3 \%)\end{array}$ & - & - \\
\hline $\begin{array}{l}\text { I found it difficult to provide } \\
\text { negative feedback }\end{array}$ & $\begin{array}{c}5 \\
(4.3 \%)\end{array}$ & $\begin{array}{c}21 \\
(18.3 \%)\end{array}$ & $\begin{array}{c}25 \\
(21.7 \%)\end{array}$ & $\begin{array}{c}56 \\
(48.7 \%)\end{array}$ & $\begin{array}{c}8 \\
(7.0 \%)\end{array}$ & - \\
\hline $\begin{array}{l}\text { I would have preferred to give } \\
\text { verbal feedback } * * *\end{array}$ & $\begin{array}{c}12 \\
(10.4 \%)\end{array}$ & $\begin{array}{c}29 \\
(25.2 \%)\end{array}$ & $\begin{array}{c}24 \\
(20.9 \%)\end{array}$ & $\begin{array}{c}33 \\
(28.7 \%)\end{array}$ & $\begin{array}{c}16 \\
(13.9 \%)\end{array}$ & $\begin{array}{c}1 \\
(0.9 \%)\end{array}$ \\
\hline $\begin{array}{l}\text { I had enough time to write my } \\
\text { feedback* }\end{array}$ & $\begin{array}{c}4 \\
(3.5 \%)\end{array}$ & $\begin{array}{c}47 \\
(40.9 \%)\end{array}$ & $\begin{array}{c}7 \\
(6.1 \%)\end{array}$ & $\begin{array}{c}46 \\
(40.0 \%)\end{array}$ & $\begin{array}{c}10 \\
(8.7 \%)\end{array}$ & $\begin{array}{c}1 \\
(0.9 \%)\end{array}$ \\
\hline $\begin{array}{l}\text { It was difficult to mark the checklist } \\
\text { without missing things }\end{array}$ & $\begin{array}{c}10 \\
(8.7 \%)\end{array}$ & $\begin{array}{c}40 \\
(34.8 \%)\end{array}$ & $\begin{array}{c}27 \\
(23.5 \%)\end{array}$ & $\begin{array}{c}34 \\
(29.6 \%)\end{array}$ & $\begin{array}{c}4 \\
(3.5 \%)\end{array}$ & - \\
\hline $\begin{array}{l}\text { It was difficult to mark someone I } \\
\text { knew }\end{array}$ & $\begin{array}{c}7 \\
(2.6 \%)\end{array}$ & $\begin{array}{c}8 \\
(7.0 \%)\end{array}$ & $\begin{array}{c}23 \\
(20.0 \%)\end{array}$ & $\begin{array}{c}20 \\
(17.4 \%)\end{array}$ & $\begin{array}{c}6 \\
(5.2 \%)\end{array}$ & $\begin{array}{c}55 \\
(47.8 \%)\end{array}$ \\
\hline $\begin{array}{l}\text { I found it helpful discussing the } \\
\text { station with the actor }\end{array}$ & $\begin{array}{c}62 \\
(53.9 \%)\end{array}$ & $\begin{array}{c}42 \\
(36.5 \%)\end{array}$ & $\begin{array}{c}8 \\
(7.0 \%)\end{array}$ & $\begin{array}{c}2 \\
(1.7 \%)\end{array}$ & - & $\begin{array}{c}1 \\
(0.9 \%)\end{array}$ \\
\hline $\begin{array}{l}\text { I found it helpful working as a } \\
\text { marker with another student }\end{array}$ & $\begin{array}{c}66 \\
(57.4 \%)\end{array}$ & $\begin{array}{c}39 \\
(33.9 \%)\end{array}$ & $\begin{array}{c}5 \\
(4.3 \%) \\
\end{array}$ & $\begin{array}{c}3 \\
(2.6 \%)\end{array}$ & - & $\begin{array}{c}2 \\
(1.7 \%)\end{array}$ \\
\hline
\end{tabular}


The majority benefited from the opportunity to discuss marking with the actor ( $90 \%$ agreed) or to work with another marker ( $91 \%$ agreed), as exemplified in the comment:

"It was so helpful being able to discuss with the actor what they thought about each student's performance and what they like to see/look for. I could then apply this for mine. This really helped me when I did my OSCE and gave me so much more confidence".

The provision of verbal feedback instead of written feedback produced a wide range of views. Positives included that it allowed a broader discussion of the station as well as less risk of misunderstanding:

"Definitely would help the student if verbal feedback was given after the station or later on in the day if that is not possible, since you can discuss the situation and alternatives to what they did. Written notes also easier to misinterpret."

Another year four student expanded on this, relating her experience of providing verbal feedback in a workshop where they had marked Year three students:
"I was able to explain some of the comments I had written in the feedback to the individual there and then, which I think is more helpful, and also made me more at ease with what I wrote down/ was not stressed about making sure I wrote things down in the best way as I knew I could explain myself afterwards to the student."

Students were also asked about the effect of marking other students for themselves (see Table V). Only three students (3\%) said they agreed that being a marker did not provide them with any benefits; most agreed (95\% agreed to some extent) that it gave them ideas of what to do/what not to do in their OSCE, $86 \%$ said it helped them understand what was expected in an OSCE and $58 \%$ said it had increased their confidence for their own OSCE. Some students expanded on their answers by explaining what these benefits were. This included understanding how the OSCEs were marked:

"Marking the OSCE is really helpful in knowing what the markers look out for"; "I realised the level of detail the actors and staff marker observed when marking students".

Table V: Impact of marking on those students who acted as markers for students in the year below - awareness and general feedback $(n=115)$ - responses shown as number $(\%)$

\begin{tabular}{|c|c|c|c|c|c|c|}
\hline & $\begin{array}{l}\text { Strongly } \\
\text { agree }\end{array}$ & Agree & $\begin{array}{l}\text { Neither } \\
\text { agree nor } \\
\text { disagree }\end{array}$ & Disagree & $\begin{array}{l}\text { Strongly } \\
\text { disagree }\end{array}$ & $\begin{array}{c}\text { Not } \\
\text { applicable }\end{array}$ \\
\hline $\begin{array}{l}\text { Being a mock OSCE marker did NOT provide me with any } \\
\text { personal benefits }\end{array}$ & - & $\begin{array}{c}3 \\
(2.6 \%)\end{array}$ & $\begin{array}{c}8 \\
(7.0 \%)\end{array}$ & $\begin{array}{c}50 \\
(43.5 \%)\end{array}$ & $\begin{array}{c}53 \\
(46.1 \%)\end{array}$ & $\begin{array}{c}1 \\
(0.9 \%)\end{array}$ \\
\hline $\begin{array}{l}\text { Marking other students gave me ideas about what to do } \\
\text { / what not to do in my own OSCE }\end{array}$ & $\begin{array}{c}65 \\
(56.5 \%)\end{array}$ & $\begin{array}{c}44 \\
(38.3 \%)\end{array}$ & $\begin{array}{c}5 \\
(4.3 \%)\end{array}$ & - & $\begin{array}{c}1 \\
(0.9 \%)\end{array}$ & - \\
\hline $\begin{array}{l}\text { Being a marker helped me to understand how staff mark } \\
\text { me in my OSCE }\end{array}$ & $\begin{array}{c}45 \\
(39.1 \%)\end{array}$ & $\begin{array}{c}52 \\
(45.2 \%)\end{array}$ & $\begin{array}{c}10 \\
(8.7 \%)\end{array}$ & $\begin{array}{c}6 \\
(5.2 \%)\end{array}$ & $\begin{array}{c}2 \\
(1.7 \%)\end{array}$ & - \\
\hline Being a marker increased my confidence for my OSCE & $\begin{array}{c}27 \\
(23.5 \%)\end{array}$ & $\begin{array}{c}40 \\
(34.8 \%)\end{array}$ & $\begin{array}{c}30 \\
(26.1 \%)\end{array}$ & $\begin{array}{c}16 \\
(13.9 \%)\end{array}$ & $\begin{array}{c}2 \\
(1.7 \%)\end{array}$ & - \\
\hline $\begin{array}{l}\text { Being a marker helped me to understand expectations of } \\
\text { what is needed in an OSCE }\end{array}$ & $\begin{array}{c}41 \\
(35.7 \%)\end{array}$ & $\begin{array}{c}58 \\
(50.4 \%)\end{array}$ & $\begin{array}{c}14 \\
(12.2 \%)\end{array}$ & $\begin{array}{c}1 \\
(0.9 \%)\end{array}$ & $\begin{array}{c}1 \\
(0.9 \%)\end{array}$ & - \\
\hline $\begin{array}{l}\text { Being a marker helped me to understand the difference } \\
\text { between the global and analytical aspects of a station }\end{array}$ & $\begin{array}{c}37 \\
(32.2 \%)\end{array}$ & $\begin{array}{c}53 \\
(46.1 \%)\end{array}$ & $\begin{array}{c}13 \\
(11.3 \%)\end{array}$ & $\begin{array}{c}11 \\
(9.6 \%)\end{array}$ & $\begin{array}{c}1 \\
(0.9 \%)\end{array}$ & - \\
\hline
\end{tabular}

One respondent summarised the benefits they obtained as:

"Can be useful to see other people's attempts at stations as this is the only time we will get to see a genuine OSCE. It can give new approaches and also show how detrimental some actions are to the overall performance".

\section{Overall comments from students}

Overall feedback on the experience of student marking of OSCEs was broadly positive:

\begin{abstract}
"The peer-marking scheme was very beneficial and allowed me to learn from other students' mistakes."

"I really benefited from marking other students OSCEs because it almost calmed me down before doing mine".
\end{abstract}

However, there was a clear message that students found (and expected) that student markers would not necessarily provide the same marks or feedback as staff members, as summarised by one student: 
"Although it is really helpful to have feedback from the year above, I think most people would agree that the feedback/marking is usually not a true reflection of how the markers in the real OSCE would mark."

There were also a number of comments relating to marks or feedback obtained whereby there was a difference between markers or where there was felt to be a paucity of quality feedback or incorrect marking:

"Each marker gave me a different mark, and one of them missed some points, which I actually discussed with the patient".

That said, the fact there were multiple markers present was able to mitigate some concerns about incomplete or inconsistent feedback:

"I feel it was beneficial to have extra people in the room as different markers pick up on different things. This contributes to more comprehensive feedback".

However, some students commented that having multiple markers present could be off-putting:

"Having the actor, the teacher and three students all watching was very intimidating and made me completely uncomfortable."

"It is initially off-putting walking into a room and immediately seeing all the markers and actor staring at you, and at times it can take a moment to identify the actor."

In addition, although student markers generally did not find it difficult to mark someone they knew, it could be problematic for the student sitting the OSCE, as one student noted:

"It's so difficult when you know the student markers - really off-putting".

Although some students would have preferred staff to mark them, this was generally seen as being in addition to peer markers:

"I would've preferred to have a staff member marking me also as they will be marking the real OSCE",

And many were happy with receiving feedback from their senior peers:

"I would've preferred to be marked by either student in the third year or more than one staff member. I feel that students write more feedback and understand the situation more than some staff members."

\section{Discussion}

This novel study set out to uncover students' views and experiences of the use of peer-marking in OSCEs, a relatively new initiative within the undergraduate pharmacy programme. Overall, students had very positive views on their role as a marker and on being marked by a peer. The feedback provided by the student markers was welcomed and supported students to understand where they did well and where there was room for improvement. Equally, the markers reported benefits for their own development, having seen, marked and discussed 'real' OSCE performances.

Students who undertook the OSCE felt comfortable receiving feedback from their peers and found it to be informative and helpful. The markers were able to provide constructive, written feedback, although time was an issue for some. Other research has likewise recognised that peers are able to provide good feedback and will impact in a positive way on student learning to enhance both ability and confidence (Davies et al., 2015; Khan, 2017). Any issues regarding allowing adequate time to provide feedback can be addressed by factoring in longer gaps between students when planning future assessments, subject to other logistical constraints.

Despite this, there were varied views regarding the consistency of markers (student marker vs student marker, or student marker vs staff marker). Student markers received training before the day, with the majority reporting that they felt prepared to mark the OSCE and they were confident to undertake their role. Providing training was imperative to understand the marking criteria, but inevitably, the student markers had only limited marking experience, and it is therefore not surprising that there were some inter-marker differences. The analytical checklist was answered in a yes/no format, allowing a more objective interpretation of the point and whether it had been fulfilled. In contrast, the global assessment mark could have been open to more interpretation. Student training, including assessment of previously recorded scenarios and test cases, aimed to overcome this by discussions around 'norms' of what a weak/strong performance looks like. However, it has been acknowledged in the literature that students need more training on the more subjective global score (Burgess et al., 2013) and that their lack of training may lead to them awarding higher scores in comparison to academic markers (Khan, 2017). It would therefore have been interesting to investigate the marks that students had provided in comparison to staff; however, this was beyond the scope of this paper which focussed on the views and experiences of the students concerned. Nevertheless, in response to this feedback, student marker training has been adapted to 
provide more guidance and practice in relation to the global scoring of candidates, alongside more focus on this in communication skills workshops where students use the OSCE mark sheets when role-playing with colleagues.

Cushing (2011) acknowledges that giving feedback to peers can be challenging, especially if it is perceived to be negative, and may not be taken on board if the person giving feedback is someone with a perceived low level of knowledge, i.e. students may be less likely to take comments on board from their peers, compared to a member of academic staff. Student markers will, as expected, have less of an understanding of the topic compared to academics or may show bias towards their fellow students (Chenot et al., 2007). Despite this, in the present study, the student markers were comfortable providing even negative feedback, and the recipients clearly valued their senior colleagues' feedback, with some explaining that the peer markers were more likely to understand how they felt as students sitting an OSCE, and the feedback would therefore be more beneficial. This may be because the present study ensured that student markers came from more senior years so they would have the prerequisite knowledge to undertake the task while still maintaining peer status. This has previously been reported in the literature with regards to near-peer tutors, who are seen as non-threatening to more junior students (Nelson et al., 2013).

Student markers' feedback also expressed positive views on the experience. Most student markers were confident in providing feedback and marks, although, perhaps unsurprisingly, year four students (who had more experience of OSCEs and the OSCE mark sheets) were more confident than year two students. Likewise, the fourth-years' increased confidence was also likely to contribute to their preference over junior colleagues to provide feedback verbally. Since undertaking nearpeer teaching and assessment in itself increases confidence to provide feedback (Khaw \& Raw, 2016), the students' confidence should continue to improve with additional opportunities to act as markers in formative OSCEs. In addition, for all student markers, the value of discussing the station with others (whether markers or simulated patients) was helpful in determining performance and the opportunity to do this should be considered when student markers are used.

This present study highlighted that the role of a marker also provided direct benefits to the student markers, namely, that it helped to inform their own OSCE and increased their understanding of what is expected of an OSCE assessment. This is echoed in a study by Burgess and authors (2013), who showed that students believed examining allowed them to apply and build on their knowledge, it also gave them an insight into the role of the examiner and what is expected of students, so they could apply this to their own practice. In terms of personal development, the student markers in the present study also found discussions with the simulated patients (actors) to be extremely useful in enhancing their understanding of what makes a good or poor performance which they could then apply to improve their own OSCEs, an unanticipated yet welcome benefit.

As well as current benefits for markers, the ability to provide peer feedback and support is a professional skill that will be important for their future practice as pharmacists. The Regulator's expectations of a pharmacy professional include the item 'Contribute to the development of other members of the team through coaching and feedback', and this is part of the Master of Pharmacy (M.Pharm.) degree educational standards (GPhC, 2011). Providing this opportunity, therefore, allows students to develop this competency in a supported and non-judgemental way from year two of the degree programme.

\section{Limitations}

Student examiners, on average, marked only four of their peers due to the size of the year groups. As a result, students were not able to build their experience to a large extent, in the same way as a staff member marking over a full day would. Nevertheless, students did comment on how the experience, even with such a limited number of marking opportunities, had been of benefit to their own development. There will also be further opportunities as they move through the programme and act as mock OSCE markers each year.

On reflection, some time to allow the markers to provide verbal feedback to their peers may have been of benefit (Young, 2014). However, the day of the OSCE is very busy and can be pressured for time. This does not allow many opportunities to formulate feedback and reflect on performance, with students moving on swiftly (Cushing, 2011). This is a difficult balance for OSCE organisers and one that the authors must reflect on to allow sufficient time to formulate feedback and process marks but within the constraints of the undergraduate timetable.

As this particular OSCE was only run in one School of Pharmacy, where the specifics of the day, marking criteria and dynamics of the undergraduate pharmacy students would be different from other schools, these 
results may not be generalisable to other OSCEs. However, the study does highlight the potential benefits to students of undertaking such an experience, and other schools may wish to consider piloting such an initiative within their own contexts.

\section{Conclusion}

The aim of this study to explore the views of student markers and those being marked by their peers was achieved. This initiative to provide students with the opportunity to formatively assess their peers proved successful, with students engaging and experiencing benefits whether they were marking or being marked. Whilst the researchers acknowledge that some improvements could be made to logistics and training to further enhance the student experience, the overwhelmingly positive findings have led to peermarking being embedded into undergraduate teaching and assessment of communication skills within the School of Pharmacy. As such, peer marking has been utilised, with positive feedback year on year, since this initiative began. The authors encourage other academics to consider making this a part of their programme to support their students in developing vital communication, consultation and coaching skills. In order to ensure successful implementation, the authors suggest that training of student markers is key to ensure they understand their role, can provide valid and reliable feedback and support the professional development of their peers.

\section{References}

Brown, C., Ross, S., Cleland, J., \& Walsh, K. (2015). Money makes the medical assessment world go round: the cost of components of a summative final year Objective Structured Clinical Examination. Medical Teacher, 37, 653-659. https://doi.org/10.3109/0142159X.2015.1033389

Burgess, A., Clark, T., Chapman, R., \& Mellis, C. (2013) Senior medical students as peer examiners in an OSCE. Medical Teacher, 35, 58-62. https://doi.org/10.3109/0142159X.2012.731101

Chenot, J. F., Simmenroth-Nayda, A., Koch, A., Fischer, T., Scherer, M., Emmert, B., Stanske, B., Kochen, M., \& Himmel, W. (2007) Can student tutors act as examiners in an objective structured clinical examination? Medical Education. 41, 10321038. https://doi.org/10.1111/j.1365-2923.2007.02895.x

Cushing, A., Abbott, S., Lothian, D., Hall, A., \& Westwood, O. (2011) Peer feedback as an aid to learning - What do we want? Feedback. When do we want it? Now! Medical Teacher, 33, e105-112. https://doi.org/10.3109/0142159X.2011.542522

Davies, A., Macleod, R., Bennett-Britton, I., McElnay, P., Bakhbakhi, D., \& Sansom, J. (2016) E-learning and near-peer teaching in electrocardiogram education: a randomised trial. The Clinical Teacher, 13, 227-230. https://doi.org/10.1111/tct.12421

Fletcher, A., \& Day, R. (2015) A peer-led mock OSCE improves subsequent performance: What about objectivity? Medical Teacher, 37, 886-886. https://doi.org/10.3109/0142159X.2015.1009432

General Pharmaceutical Council (2011). Future pharmacists. Standards for the initial education and training of pharmacists. Available at: https://www.pharmacyregulation.org/sites/default/files/ document/gphc future pharmacists may 2011.pdf

General Pharmaceutical Council (2020). Pharmacist education and training. Available at: https://www.pharmacyregulation.org/education/pharmacis t-education

Harden, R. M., Stevenson, M., Downne, W., \& Wilson, G. (1975). Assessment of clinical competence using objective structured clinical examination (OSCE). British Medical Journal, 1, 447-451. https://doi.org/10.1136/bmj.1.5955.447

Harris, I., \& Miller, W. (1990) Feedback in an Objective Structured Clinical Examination by medical students serving as patients, examiners and teachers. Academic Medicine, 65, 433-434. https://doi.org/10.1097/00001888-199007000$\underline{00002}$

Iblher, P., Zupanic, M., Karsten, J., \& Brauer, K. (2015) May student examiners be reasonable substitute examiners for faculty in an undergraduate OSCE on medical emergencies? Medical Teacher, 37, 374-378. https://doi.org/10.3109/0142159X.2014.956056

Kelly, M., \& Murphy, A. (2004). An evaluation of the cost of designing, delivering and assessing an undergraduate communication skills module. Medical Teacher, 26, 610-614. https://doi.org/10.1080/01421590400005475

Khan, R., Payne, M., \& Chahine, S. (2017). Peer assessment in the objective structured clinical examination. Medical Teacher, 39, 745-756. https://doi.org/10.1080/0142159X.2017.1309375

Khaw, C., \& Raw, L. (2016) The outcomes and acceptability of near-peer teaching among medical students in clinical skills. International Journal of Medical Education, 7, 188-194. https://doi.org/10.5116/ijme.5749.7b8b

Miller, G. E. (1990). The assessment of clinical skills /competence /performance. Academic Medicine, 65, 563-7. https://doi.org/10.1097/00001888-199009000-00045

Moineau, G., Power, B., Pion, A., Wood, T., \& HumphreyMurto, S. (2011) Comparison of student examiner to faculty examiner scoring and feedback in an OSCE. Medical Education, 45, 183-191. https://doi.org/10.1111/j.13652923.2010.03800.x

Nelson, A. J., Nelson, S.V., Linn, A. M. J., Raw, L., Kildea, H. B., \& Tonkin, A. L. (2013). Tomorrow's educators ... today? Implementing near-peer teaching for medical students. Medical Teacher, 35, 2, 156-159. https://doi.org/10.3109/0142159X.2012.737961

Ogden, G. R., Green, M., \& Ker, J. S. (2000). The use of interprofessional peer examiners in an objective structured clinical examination: Can dental students act as examiners? British Dental Journal, 189, 160-164. https://doi.org/10.1038/sj.bdj.4800711

Quero Munoz, L., O’Byrne, C., Pugsley, J., \& Austin, Z. (2005) Reliability, validity, and generalizability of an objective structured clinical examination (OSCE) for assessment of 
entry-to-practice in pharmacy. Pharmacy Education, 1-12. https://doi.org/10.1080/15602210400025347

Saunders, A., Say, R., Visentin, D., \& McCann, D. (2019). Evaluation of a collaborative testing approach to objective structured clinical examination (OSCE) in undergraduate nurse education: A survey study. Nurse Education in Practice, 35, 111-116. https://doi.org/10.1016/j.nepr.2019.01.009

Young, I., Montgomery, K., Kearns, P., Hayward, S., \& Mellanby, E. (2014). The benefits of a peer-assisted mock OSCE. The Clinical Teacher, 11, 214-218. https://doi.org/10.1111/tct.12112

Zhang, N., \& Rabatsky, A. (2015). Effects of test stress during an objective structured clinical examination. The Journal of Chiropractic Education, 29, 139-144. https://doi.org/10.7899/JCE$\underline{14-17}$ 